\author{
Wlodzimierz Kurek \\ Zakład Gospodarki Turystycznej i Uzdrowiskowej \\ Uniwersytet Jagielloński \\ 31-044 Kraków \\ ul. Grodzka 64 \\ W.Kurek@interia.pl
}

\section{TURYSTYCZNA FUNKCJA OBSZARÓW GÓRSKICH}

\section{THE TOURISM FUNCTION OF MOUNTAIN AREAS}

\begin{abstract}
Zarys treści: Artykuł ukazuje stan obecny i prognozy rozwoju turystyki na obszarach górskich. Autor w szczególności zwróca uwagę na: koncentrację przestrzenną turystyki, sezonowość, problemy komunikacyjne, formy ruchu turystycznego (turystyka piesza, narciarstwo, turystyka wiejska), a także na koncepcje harmonijnego rozwoju turystyki. Najbardziej pożądane jest stosowanie się do zasad zrównoważonego rozwoju.
\end{abstract}

Słowa kluczowe: obszary górskie, turystyka, zrównoważony rozwój.

\section{UWAGI OGÓLNE}

Obszary górskie są obok terenów nadmorskich najważniejszymi regionami turystycznymi. Ich atrakcyjność związana jest $\mathrm{z}$ bogatymi zasobami przyrodniczymi i kulturowymi, na które składają się: różnorodność krajobrazowa, duża lesistość, pionowa strefowość roślinności, zróżnicowanie klimatyczne, czyste rzeki i potoki oraz w dużym stopniu zachowana tradycyjna kultura ludowa. Zasoby przyrodnicze i kulturowe obszarów górskich wykorzystywane są w różnym stopniu w poszczególnych regionach. Na większości obszarów dominują nadal tradycyjne gałęzie gospodarki - rolnictwo i leśnictwo. Dużą część regionów górskich stanowią już jednak tereny intensywnie wykorzystywane turystycznie, na których turystyka jest najważniejszą dziedziną gospodarki.

Największym górskim regionem turystycznym Świata są Alpy. Turystyka zaczęła się tu rozwijać już w drugiej połowie XVIII w. Pierwszym okresem intensywnego rozwoju turystyki była druga połowa XIX w., co wiązało się z budową sieci linii kolejowych. Drugim okresem dynamicznego rozwoju turystyki były lata po II wojnie światowej.
Abstract: The article presents both current and prospective tourism development in mountain areas. The author pays particular attention to the spatial concentration of tourism, its seasonality, transport problems and activities (hiking, skiing and agro-tourism) as well as to ideas for harmonious tourism development. Sustainable development being seen as the most desirable option.

Key words: mountain areas, tourism, sustainable development.

\section{GENERAL REMARKS}

Next to coastal areas, mountains are the most important tourism regions. Their attractiveness lies in their rich natural and cultural resources including varied landscapes, vast forests, altitudinal vegetation zones, climatic variety, clean rivers and streams etc., as well as well preserved traditional folklore. The natural and cultural resources of mountain areas are exploited differently in individual regions and in the majority the traditional economic sectors - agriculture and forestry still predominate. However a significant proportion are intensively exploited for tourism purposes and tourism is the leading economic activity.

The Alps are the largest mountain tourism region in the world. Tourism began to develop there in the second half of the $18^{\text {th }} \mathrm{c}$ while the first period of intensive development was the second half of the $19^{\text {th }} \mathrm{c}$. coinciding with railway expansion. A second period of dynamic 
Na początku tego okresu rozwijała się głównie turystyka w sezonie letnim, natomiast lata 19651980 charakteryzowały się intensywnym rozwojem turystyki zimowej. Od lat osiemdziesiątych w turystyce alpejskiej obserwuje się zastój. Stan ten tłumaczyć można spadkiem popularności ośrodków narciarskich wskutek złych warunków śniegowych, licznych katastrof naturalnych, zwłaszcza lawin, a także mniejszym zainteresowaniem wypoczynkiem w ośrodkach turystyki letniej, które na skutek intensywnego zagospodarowania turystycznego (wielkie hotele, wyciagi, nartostrady, drogi i inne) stały się mniej atrakcyjne dla turystów. Poza tym w wyniku zmian socjalnych, ekonomicznych, demograficznych i społecznych kształtuje się nowy model wypoczynku ludności krajów Europy Zachodniej. Obecnie czas urlopowy jest często dzielony na trzy lub więcej krótszych wyjazdów o różnych motywacjach i do różnych miejscowości, np. zima w Alpach, lato nad morzem, wyjazdy na inne kontynenty, turystyka kulturowa w miastach itd.

W regionach górskich Europy Środkowej i Wschodniej rozwój turystyki był słabszy i w związku z tym nie spowodował tak znaczących przeobrażeń środowiskowych i społeczno-kulturowych, jak w Alpach. Typowym przykładem są obszary górskie w Polsce - Karpaty i Sudety. Po II wojnie światowej turystyka miała tu w dużym stopniu charakter uspołeczniony, toteż wyjazdy do ośrodków wypoczynkowych cieszyły się dużą popularnością. Na początku lat 90 . XX w., czyli w okresie transformacji gospodarczej, nastapił duży spadek ruchu turystycznego spowodowany likwidacją socjalnego charakteru turystyki. Jeszcze do tej pory w wielu regionach górskich Europy Środkowej i Wschodniej wielkość ruchu turystycznego nie osiagnęła stanu sprzed okresu transformacji. Jednak $w$ tych regionach należy się spodziewać dalszego wzrostu ruchu turystycznego, co można wnioskować na podstawie dużego tempa rozwoju gospodarczego i niskiej jeszcze aktywności turystycznej ludności tych krajów.

\section{KONCENTRACJA PRZESTRZENNA}

Na obszarach górskich koncentracja ruchu turystycznego i bazy turystycznej jest duża, ponieważ skupiają się one tylko $\mathrm{w}$ niektórych regionach i miejscowościach. W związku z tym występują tu problemy komunikacyjne i środowiskowe, np. development followed World War II. At the beginning tourism developed mainly in summer however from 1965-1980 it started to flourish in winter as well.

In the 1980s growth in Alpine tourism came to a standstill which can be explained by the falling popularity of skiing resorts. This was a result of poor snow conditions, numerous natural disasters (especially avalanches), as well as a lessening of popularity of summer tourism resorts due to intensive development of tourism infrastructure (large hotels, ski lifts, ski runs, roads, etc.) making them less attractive. Moreover, as a result of social, economic and demographic changes, a new model of recreation was emerging in West European countries. Nowadays holidays are often divided between three or more shorter trips to different destinations for different purposes, e.g. winter in the Alps, summer at the seaside, trips to other continents, cultural tourism in cities, etc.

In the mountain regions of Central and Eastern Europe the development of tourism was less dynamic and as such it did not cause such significant environmental and socio-cultural changes as was the case in the Alps. Typical examples are the Carpathian and the Sudeten Mountains in Poland. After World War II tourism was largely subsidised by the state, so holidays spent at recreation centres were very popular. In the early 1990s, i.e. in the period of economic transformation, tourism activity decreased considerably as it was no longer a social welfare phenomenon. In many mountain regions of Central and Eastern Europe, tourism activity is still less than before the transformation period. However, further tourism development can be expected, judging from rapid economic growth and the presently limited tourism activity in these countries.

\section{SPATIAL CONCENTRATION}

In mountain areas tourism and the concentration of tourism infrastructure are considerable because they occur only in certain regions and destinations resulting in transport and environmental 
ścieków komunalnych. Obok tego istnieją rozległe obszary nie odgrywające żadnej roli w turystyce. Są to np. części podgórskie i niższe partie gór, zwłaszcza te, na których wyniszczone zostały lasy. Na przykład w Alpach aż w $40 \%$ gmin w ogóle nie ma turystyki, a tylko $10 \%$ gmin odznacza się monofunkcyjnym charakterem turystyki (http://reports.eea.eu.int/92-826-5409-5/en/page 025new.html). Niektóre ośrodki starają się przeciwdziałać problemowi koncentracji ruchu turystycznego poprzez rozwój ośrodków satelitarnych. Ich rozwojowi sprzyjają między innymi niższe ceny ziemi i korzystniejsze warunki do wypoczynku (mniejszy hałas, mniejsze zanieczyszczenie środowiska). Takimi przykładami regionów turystycznych typu „satelitarnego" są obszary wokół Arlberga w Austrii, Cortiny d'Ampezzo i Madonny di Campiglio we Włoszech, St. Moritz w Szwajcarii czy okolice Zakopanego w Polsce.

Część turystów wypoczywających w górach stanowią osoby przybywające tu na krótko, najczęściej na weekendy, a część na dłużej, zwłaszcza na czas urlopu. W tym pierwszym wypadku terenami koncentracji ruchu turystycznego są łatwo dostępne i atrakcyjne góry sąsiadujące $\mathrm{z}$ dużymi miastami, w drugim zaś ośrodki turystyczne dysponujące odpowiednią bazą turystyczną noclegowo-żywieniową i urządzeniami sportowo-rekreacyjnymi.

W Alpach największą liczbę turystów weekendowych generuje Monachium. Stanowią oni większość turystów w Alpach Bawarskich, a także liczną grupę turystów w Tyrolu i Vorarlbergu. Mieszkańcy Wiednia stanowią większość turystów w Dolnej Austrii i Burgerlandzie, mieszkańcy Mediolanu wyjeżdżają nad jeziora Como i Maggiore, a mieszkańcy Lubliany do Karawanek. W Szwajcarii połowa kraju to tereny turystyki weekendowej. Stanowią one obszary wypoczynkowe dla mieszkańców Zurichu, Genewy, Lozanny i Lucerny. W Polsce Karpaty są terenami wypoczynku dla mieszkańców Krakowa i GOP-u.

\section{SEZONOWOŚć}

Sezonowość to charakterystyczna cecha ruchu turystycznego. Powoduje ona fluktuację dochodów z usług turystycznych, zaś krótki sezon jest powodem niskiej opłacalności inwestycji turystycznych. W związku z tym w miejscowościach problems such as sewage disposal. Apart from this there are vast areas which do not play any role in tourism, e.g. the foothills and the lower sections of the mountains particularly those where forests have been destroyed. In the Alps, in as many as $40 \%$ of gminas there is no tourism at all, and in $10 \%$ only mono-functional tourism occurs (http://reports.eea.eu.int/92-826-5409-5/ en/page025new.html). Some centres are trying to solve the problem of tourism concentration by developing satellite resorts and spreading rapidly due to lower land prices and more favourable recreational conditions (less noise and pollution). Examples of satellite tourism regions are the areas around Arlberg in Austria, Cortina d'Ampezzo and Madonna di Campiglio in Italy, St. Moritz in Switzerland or Zakopane in Poland.

A proportion of the tourists in the mountains are those arriving for a short stay, usually for the weekend, while others come for longer visits especially during holidays. In the first case areas of tourism concentration are those easily accessible and attractive mountains close to large cities, and in the other they are tourism resorts with appropriate infrastructure: hotels, restaurants, and sport and recreation facilities.

In the Alps the largest number of weekend tourists arrive from Munich making up a majority in the Bavarian Alps, and a sizeable group in Tyrol and Vorarlberg. The Viennese dominate in Lower Austria and Burgerland, and the Milanese at Lakes Como and Maggiore, while those from Ljubljana go to Karavanki. As much as one half of Switzerland could be visited by weekend tourists from Zurich, Geneva, Lausanne and Lucerne. In Poland the Carpathian Mountains are the recreation areas for Kraków and Upper Silesia.

\section{SEASONALITY}

Seasonality is typical of tourism. It produces an annual fluctuation in income from tourism services, and a short tourism season is the cause of the low cost-effectiveness of tourism investments. 
turystycznych często podejmuje się próby wydłużania sezonu, poprzez stwarzanie dodatkowych atrakcji czy stosowanie niższych cen usług turystycznych poza sezonem i pakietu ofert po cenach zniżkowych w okresie przed i po sezonie.

Główne czynniki sezonowości w turystyce są natury przyrodniczej - zwłaszcza klimat. Poza tym na sezonowość wpływają okresy wolne od pracy, a przede wszystkim okresy świąteczne. W górskich ośrodkach turystycznych występują najczęściej dwa sezony - letni i zimowy (dokładnie jest to sezon narciarski). Są też jednak miejscowości, w których występuje tylko sezon letni lub tylko zimowy.

Problem sezonowości można zilustrować przykładem Tyrolu. W lutym 2003 r. udzielono tu 6,9 mln noclegów, w sierpniu 5,0 mln, natomiast w maju tylko $2,0 \mathrm{mln}$, a w listopadzie zaledwie $0,7 \mathrm{mln}$ (TIROL 2004).

\section{PROBLEMY KOMUNIKACYJNE}

Głównym środkiem transportu w podróżach turystycznych na obszarach górskich, tak jak i w całej Europie, są samochody osobowe. Dla przykładu na obszarach górskich we Francji aż 76\% turystów podróżuje własnymi samochodami (Les chiffres..., 2001).

Szacuje się, że w ciągu roku przez Alpy przejeżdża ok. $50 \mathrm{mln}$ samochodów osobowych. Intensywny ruch i wielokilometrowe korki samochodowe widoczne są zwłaszcza w okresie wyjazdów wakacyjnych (Tourism and Recreation 2001). Następstwem tak dużego ruchu samochodowego jest duże zanieczyszczenie powietrza spalinami samochodowymi. Problem ten pogłębia fakt, że w dolinach górskich wymiana powietrza jest utrudniona, a częste inwersje temperatur sprzyjają koncentracji zanieczyszczeń. Największe stężenie zanieczyszczeń powietrza występuje w zimie.

W celu ochrony powietrza i eliminacji hałasu niektóre ośrodki (np. Zermatt, Saas-Fee, Riederalp, Kühboden) tworzą strefy wolne od ruchu samochodowego.

Trasy komunikacyjne prowadzące przez obszary górskie, poza ich główną rolą w przewozach towarów i pasażerów, mają duże znaczenie jako forma turystyki poznawczej. Liczne linie kolejowe prowadzące wzdłuż dolin rzecznych i pokonujące przełęcze i tunele, umożliwiające podziwianie krajobrazów górskich, stanowią dużą atrakcję turystyczna.
Therefore, attempts to prolong the tourism season are often made by creating additional attractions or offering lower prices for tourism services outside the season and a reduced price package offers just before and after the main season.

The main seasonality factors in tourism are nature-related, such as climate, but it is also modified by the pattern of nonworking days and above all the holiday periods. In mountain resorts two seasons are recognised - summer and winter (the skiing season) but there are, however, destinations with only a summer or only a winter season.

The problem of seasonality can be illustrated by the example of the Tyrol. In February 20036.9 million beds were rented there, in August - 5.0 million, in May only 2.0 million, and in November 0.7 million (TYROL 2004).

\section{TRANSPORT PROBLEMS}

The main means of transport in mountain areas, as in the whole of Europe, is the private car, for instance in the French mountains $76 \%$ of tourists use their own cars (Les chiffres..., 2001).

It is estimated that within a year the Alps are crossed by about 50 million private cars. Heavy traffic and long traffic jams can be found particularly during holidays (Tourism and Recreation 2001). Such traffic results in serious air pollution which becomes even worse if the fact that in mountain valleys difficulties in the exchange of air is considered, and there are frequent temperature inversions, peaking in winter, conducive to pollution concentration. In order to protect the air and eliminate noise, some resorts (e.g. Zermatt, Saas-Fee, Riederalp, Kuhoden), have established traffic-free zones.

Apart from transporting goods and passengers, the routes crossing the mountains are important in themselves as a form of tourism. The numerous railways running along river valleys and through mountain passes and tunnels enable the tourists to admire the landscape and are a great tourism attraction. 
Również drogi są interesującymi i popularnymi trasami turystycznymi. Można podać przykład Grossglockner Hochalpenstrasse poprowadzoną przez wysokie partie Hohe Tauern (Austria), którą przejeżdża rocznie ponad $1 \mathrm{mln}$ turystów.

\section{ROLA TURYSTYKI ZAGRANICZNEJ}

W górach zachodniej Europy istotną rolę w ruchu turystycznym odgrywa turystyka zagraniczna. W Alpach austriackich turyści zagraniczni stanowią 70\% ogólnej liczby turystów, w szwajcarskich - 50\%, a we włoskich - 30\%. Występuje przy tym duża dominacja turystów z jednego kraju, tj. z Niemiec (w Austrii $60 \%$, w Szwajcarii i we Włoszech ok. 40\%). Jest to zjawisko niekorzystne, ponieważ sytuacja ekonomiczna turystyki w Alpach zależy w dużym stopniu od wielkości przyjazdowego ruchu turystycznego z Niemiec.

Z kolei w krajach Europy Środkowo-Wschodniej udział turystów zagranicznych wypoczywających w regionach górskich jest niewielki. W Polsce w powiatach górskich procent turystów zagranicznych wynosi średnio ok. 4; najwięcej w powiatach: tatrzańskim $-10,6 \%$, jeleniogórskim $-8,7 \%$ i kłodzkim 7,3\%.

\section{FORMY RUCHU TURYSTYCZNEGO}

Najważniejszymi formami ruchu turystycznego sa turystyka piesza i narciarstwo. Poza tym jednak duże znaczenie mają: turystyka kulturowa, lecznictwo uzdrowiskowe, turystyka poznawcza w parkach narodowych, agroturystyka, kolarstwo górskie i turystka konna.

Zasoby przyrody i dóbr kultury w największym stopniu wykorzystuje turystyka piesza. Jest ona jednym $z$ najlepszych sposobów poznawania przyrody i krajobrazów, zabytków i kultury ludowej oraz współczesnego życia mieszkańców odwiedzanego regionu. Dużą zaletą wędrówek pieszych jest też możliwość wyboru tras z dala od przepełnionych ośrodków turystycznych i masowej turystyki. Turyści, którzy wędrują szlakami turystycznymi, to zazwyczaj miłośnicy przyrody i osoby wrażliwe na piękno krajobrazów.

Istotne są też walory zdrowotne turystyki pieszej, gdyż korzystnie oddziałuje ona na organizm człowieka, powodując wzmocnienie sił psychofizycznych. W regionach górskich dodatkowym czynnikiem jest też klimat, który wpływa dobroczynnie na układ krwiotwórczy i drogi oddechowe.
Roads too form interesting and popular tourism routes e.g. Grossglockner Hochalpenstrasse, which runs through the upper parts of Hohe Tauern (Austria) and is used by over one million tourists every year.

\section{FOREIGN TOURISM}

In the mountains of Western Europe foreign tourism plays a significant role. In the Austrian Alps foreign tourists constitute $70 \%$ of the overall number, in the Swiss Alps - 50\%, and in the Italian Alps - 30\%. German tourists are the dominant group (in Austria - 60\%, in Switzerland and Italy - c. $40 \%$ each) which is unfavourable as the economic situation of tourism in the Alps largely depends on these tourists.

In Central and Eastern European countries the percentage of foreign tourists is low. In Poland the average number in mountain powiats is $4 \%$, with the highest figures in the Tatrzański powiat - 10.6\%, Jeleniogórski powiat - 8.7\%, and Kłodzki powiat - 7.3\%

\section{FORMS OF TOURISM}

The most important forms of tourism are hiking and skiing while in addition cultural tourism, spa therapy, educational tourism in national parks, agrotourism, mountain cycling and horseriding also figure.

Natural and cultural resources are mostly exploited through walking which is one of the best ways to learn about nature and landscape, historical monuments and folklore, as well as the contemporary life of the inhabitants. Another advantage is the opportunity to choose trails far from overcrowded resorts and mass tourism centres and those who walk the tourism trails are usually nature lovers, sensitive to the beauty of landscapes. The health aspect is equally important, as it makes people fit and relaxed at the same time while an additional factor is the mountain climate, good for the blood and respiratory systems. 
Narciarstwo stało się w niektórych regionach jednym z najważniejszych czynników rozwoju ekonomicznego, ważnym źródłem miejsc pracy i dochodów mieszkańców. Jednakże poza korzyściami ekonomicznymi, narciarstwo wywiera negatywny wpływ na środowisko przyrodnicze obszarów górskich. Środowisko to jest bowiem szczególnie podatne na degradację.

Jeśli idzie o popularność narciarstwa wśród Europejczyków, to najchętniej sport ten uprawiają Niemcy - 5,3 mln, Francuzi - 5,3, Włosi - 2,9, Austriacy - 2,5 i Szwajcarzy - 2,4. W grupie narciarzy przeważają mężczyźni - 55,4\% (BACHLEITNER 1998).

Prognozy dotyczące turystyki narciarskiej oparte na trendach demograficznych nie są optymistyczne. Ta forma aktywnej turystyki jest uprawiana głównie przez osoby młode i sprawne fizycznie. Według badań Bässler (1996) (za: BACHLEITNER 1998) w grupie wiekowej 15-24 lata narciarstwo uprawia 70\% osób, w grupie 25-34 lata-61\%, zaś w grupie wiekowej 55-64 lata - 30\% i w grupie wiekowej $65-74-13 \%$ osób. Tymczasem przewiduje się, że w przyszłych latach nadal postępować będzie proces starzenia się demograficznego ludności krajów europejskich.

Kolejnym czynnikiem ograniczającym rozwój turystyki narciarskiej jest ocieplanie się klimatu. BREILING I CHARAMZA (1999) na podstawie przeprowadzonych badań w wybranych regionach alpejskich położonych na wysokości 400-2800 m n.p.m. stwierdzili, że ocieplenie klimatu będzie miało negatywny wpływ na pokrywę śnieżną, a co za tym idzie na turystykę zimową. Ocieplenie spowoduje redukcję śniegu we wszystkich regionach i zmniejszenie powierzchni terenów narciarskich. Stacje narciarskie położone na niższych wysokościach nad poziomem morza upadna, ponieważ będą ekonomicznie nieopłacalne. Dotyczy to na przykład Les Portes du Soleil w Szwajcarii, Kitzbuehel w Tyrolu i Kranjskej Gory w Słowenii.

Polityka państw dotycząca regionów narciarskich koncentruje się od lat 90. XX w. na działaniach mających na celu wyjście z kryzysu w rozwoju ośrodków sportów zimowych.

We Francji z inicjatywy Ministerstwa Turystyki powstał plan „poprawy jakości w turystyce na obszarach górskich". Najpierw dotyczył ośrodków sportów zimowych, ale potem był sukcesywnie poszerzany na inne ośrodki o funkcji turystycznej.

Plan zakładał między innymi następujące działania:
In some regions skiing has become one of the most important factors of economic growth, and an important source of employment and income for the local inhabitants. However, outside its economic benefits, skiing negatively affects the natural environment of mountain areas which are particularly sensitive to degradation. Germany and France are the leaders with 5.3 million skiers each, followed by Italy with 2.9 million, Austria with 2.5 million and Switzerland with 2.4 million. A majority of skiers are male 55.4\% (BACHLEITNER 1998).

Predictions for skiing tourism, based on demographic tendencies, are not optimistic. It is done mainly by young, fit people and, according to BASSLER (1996) (after BACHLEITNER 1998), including 70\% from the 15-24 age group, $61 \%$ from the $25-34,30 \%$ from the 55-64 and 13\% from the 65-74. The current prognosis however assumes that the European demographic trend of ageing will continue to grow.

Another factor limiting the development of skiing tourism is climate warming. Having conducted research in selected Alpine regions at altitudes from 400$2800 \mathrm{~m}$ above sea level, BrEILING and CHARAMzA (1999) claimed that climate warming would seriously affect the snow layer, and consequently winter tourism, reducing snow in all regions and decreasing the skiing area. Skiing stations situated at lower altitudes will be closed down because they will not be costeffective (e.g. Les Portes du Soleil in Switzerland, Kitzbuehel in Tyrol and Kranjska Gora in Slovenia). Since the 1990s policy regarding skiing areas has been oriented towards overcoming the crisis in the development of winter sports resorts.

In France the Ministry of Tourism has proposed a plan to 'improve the quality of mountain tourism', at first concerning winter sports resorts only, but later including other centres with a tourism function. The plan included the following proposals:

- reorganising transportation within the resorts (building paths for hikers, 
- reorganizację komunikacji w obrębie ośrodków (budowa dróg dla pieszych, oddzielenie ruchu samochodowego, rozwój publicznego transportu);

- reorganizację funkcjonowania sieci usługowej, w tym godzin otwarcia sklepów;

- rewitalizację historycznego dziedzictwa i tradycyjnego budownictwa;

- wprowadzenie innych atrakcji poza narciarstwem, również na wypadek złej pogody;

- reorganizację funkcjonowania wyciągów.

\section{TURYSTYKA WIEJSKA}

Obszary wiejskie są popularne w całej Europie jako tereny recepcyjne turystyki. Szacuje się, że turystyka wiejska stanowi w krajach europejskich $10-20 \%$ wszystkich form i że $23 \%$ turystów wybiera na wypoczynek tereny wiejskie (Tourism and Recreation 2001). Turystyka wiejska należy ponadto do najszybciej rozwijających się segmentów rynku turystycznego. Ważną jej cechą jest to, że na ogół jest ona domeną działalności społeczności lokalnej.

Turystyka wiejska jest najlepiej rozwinięta i ma najdłuższe tradycje w Austrii, w Szwajcarii, w Niemczech, we Francji, we Włoszech, w Wielkiej Brytanii, w Polsce i w Czechach.

Do najkorzystniejszych form turystyki należy promowana ostatnio agroturystyka, czyli wypoczynek w gospodarstwach rolnych. Obecny stan i perspektywy rozwoju agrotırystyki w poszczególnych krajach i regionach uwarunkowane są wieloma czynnikami. Niewątpliwie do najważniejszych należa: konkurencyjność innych form turystyki oraz atrakcyjność wypoczynku na wsi. Można podać przykład Hiszpanii, gdzie mimo oficjalnie sponsorowanego programu wypoczynku w gospodarstwach rolnych (vacaciones en casas de labran$z a)$ nie przyniósł on spodziewanych rezultatów (WEATHERLEY, NAYLON 1984). Obszary wiejskie nie są bowiem $w$ stanie zaoferować atrakcyjniejszych warunków wypoczynku niż tereny nadmorskie.

Możliwości rozwoju turystyki na terenach wiejskich są największe w regionach odznaczających się dużą atrakcyjnością przyrodniczą i kulturową. Należą do nich obszary górskie.

W polskich Karpatach wypoczynek w tzw. wsiach letniskowych był popularny już w okresie międzywojennym. Po II wojnie światowej największy udział $w$ bazie noclegowej stanowiły pokoje wynajmowane przez mieszkańców wsi. Więk- separating motor traffic, developing public transport);

- reorganising the service network including shop opening hours;

- revitalising the historical heritage and traditional architecture;

- introducing attractions apart from skiing in case the weather is bad;

- reorganising ski-lift operation.

\section{RURAL TOURISM}

Rural areas are popular all over Europe as tourism reception areas. It is estimated that rural tourism makes up 10-20\% of all forms of tourism in Europe and that $23 \%$ of tourists choose the countryside for recreation (Tourism and Recreation 2001). What is more, rural tourism is one of the fastest developing segments of the tourism market and is usually under local control. Rural tourism is best developed and has the longest traditions in Austria, Switzerland, Germany, France, Italy, Great Britain, Poland and the Czech Republic.

One form of tourism recently promoted is agro-tourism; recreation at farms. The present state and development prospects for agro-tourism in individual countries and regions depend on many factors such as the competitiveness of other forms of tourism and the attractiveness of recreation in the countryside. The example of Spain can be quoted where the officially sponsored programme of recreation on farms (vacaciones en casas de labranza) did not bring the expected results (WEATHERLEY \& NAylon 1984). It is not possible for rural areas to offer more attractive conditions than seaside areas and tourism development possibilities are strongest in very attractive regions for both nature and culture, and mountains belong to this group.

In the Polish Carpathian Mountains rural tourism in 'summer villages' was already popular in the interwar period. After World War II the largest proportion of tourism accommodation were the rooms let by village inhabitants and the 
szość tego typu miejsc noclegowych wynajmowana była przez właścicieli gospodarstw rolnych. Gospodarstwa te można zatem uważać za pierwszą formę gospodarstw agroturystycznych. Obecnie gospodarstwa agroturystyczne muszą spełniać odpowiednie kryteria co do standardu usług noclegowych, żywieniowych i umożliwiać realizowanie różnych form rekreacji, w tym związanych z zajęciami wiejskimi.

W Niemczech, począwszy od lat 60., jednym z elementów planu rozwoju kraju była promocja wypoczynku w gospodarstwach rolnych, a już w latach 70. wypoczynek na farmach stanowił 4 5\% ruchu krajowego. Obecnie nadal obserwuje się tendencję wzrostu liczby turystów w regionach wiejskich. Liczba noclegów udzielanych w gospodarstwach rolnych $w$ Niemczech wynosi ok. $27 \mathrm{mln}$, z czego $30 \%$ przypada na Bawarię.

Austria, dzięki bogatym zasobom przyrodniczym i kulturowym, należy do krajów o najlepiej rozwiniętej gospodarce turystycznej. Duże znaczenie w tym kraju ma turystyka wiejska i agroturystyka. Już w okresie międzywojennym w gospodarstwach rolnych $w$ regionie Tyrolu, Vorarlbergu i Salzburger Land wypoczywało wielu turystów. Silny rozwój ruchu turystycznego nastapił jednak w Austrii po wojnie. Duże zmiany na terenach wiejskich spowodował zwłaszcza rozwój turystyki zimowej. Wiele wsi przekształciło się w ośrodki narciarskie. Ponadto zaczęto wykorzystywać dla narciarstwa liczne hale, którc wcześniej były terenami pasterskimi. Dzięki turystyce tysiące gospodarstw zachowało się i zmodernizowało (LICHTENBERGER 1975). Jedna szósta wszystkich miejsc noclegowych na obszarach górskich Austrii znajduje się właśnie w gospodarstwach agroturystycznych. Goście przebywający w gospodarstwach agroturystycznych wydają przeciętnie mniej pieniędzy niż turyści korzystający z innych rodzajów bazy noclegowej. Agroturystyka jest zatem nadal tańszą formą wypoczynku niż inne. Główną grupą korzystającą z wypoczynku w gospodarstwach agroturystycznych są rodziny z małymi dziećmi. Z gospodarstw korzystają ponadto zwolennicy ekoturystyki i turystyki kwalifikowanej (konnej, wędkarstwa) (EMBACHER 2001).

We Francji $1 / 3$ ruchu turystycznego przypada na obszary wiejskie, co oznacza, że zajmują one pierwsze miejsce wśród turystycznych terenów recepcyjnych. Pobyt na obszarach wiejskich we Francji jest znacznie tańszy niż gdzie indziej. Na przykład w $2001 \mathrm{r}$. koszty jednodniowego pobytu na obszarach wiejskich wynosiły 26 euro, nad mo- majority were offered by farm owners. Those farms can then be considered to have been the first agrotourism farms. At present such farms have to match fixed criteria regarding the standard of accommodation and food, as well as creating conditions for alternative forms of recreation including those which involve farm work.

Starting in the 1960s one of the elements of the national development plan for Germany was the promotion of recreation at farms which in the 1970s constituted $4-5 \%$ of national tourism, and currently there are a growing number of tourists in rural areas. The number of beds used by tourists on German farms is about 27 million, 30\% of which are in Bavaria.

Owing to its rich natural and cultural resources, Austria is among those countries with the best-developed tourism economy, and rural tourism and agrotourism are of great importance. As early as the interwar period many tourists spent their holidays at farms in the Tyrol, Vorarlberg and Salzburger Land. However, the true development of tourism in Austria came after the war when the development of winter tourism in particular caused considerable changes in rural areas. Many villages were transformed into skiing resorts, many alpine meadows began to be exploited for skiing and thousands of farms survived and modernised as a result of tourism (LiCHTENBERGER 1975). One sixth of all rented beds in Austrian mountain areas can be found on agro-tourism farms and guests staying there usually spend less money than tourists using other kinds of accommodation. Agro-tourism is cheaper than other forms of tourism mostly undertaken by families with small children, followed by eco-tourists and those taking part in sustainable tourism (horse-riding and fishing) (EMBACHER 2001).

In France a third of tourism activity occurs in rural areas which are therefore the most important tourism reception areas. Staying in the French countryside is considerably cheaper than elsewhere, 
rzem 34 euro, a w mieście aż 45 euro. Wynika to między innymi z mniejszej oferty turystyczno-rozrywkowej terenów wiejskich. Również we Francji, jak wykazują badania, turyści korzystający z wypoczynku w gospodarstwach agroturystycznych należą do grupy mniej zamożnych. Są to zwłaszcza rodziny z dziećmi $(60 \%)$ (http://www. ifen.fr/presse/dostour.htm).

\section{TURYSTYKA NA OBSZARACH CHRONIONYCH}

Jak wiadomo, obszary chronione tworzone są głównie $w$ celu zachowania cennej przyrody i dziedzictwa kulturowego oraz dla celów rekreacyjnych i edukacyjnych.

Turystyka i ochrona przyrody są ściśle ze sobą powiązane. Turystyka często stymuluje tworzenie obszarów chronionych, $\mathrm{z}$ drugiej jednak strony może być dla nich zagrożeniem. Jest ono tym większe, im większy jest popyt na wypoczynek na obszarach o wysokich walorach przyrodniczych (JAFARI 2000).

Zainteresowanie obszarami chronionymi dla celów turystyczno-rekreacyjnych będzie szybko wzrastało. Składa się na to wiele czynników. Jednym z nich jest wzrost zainteresowania turystyką poznawczą, przyrodniczą, ekoturystyką itp., które na terenach górskich mają dobre warunki rozwoju. Inną istotną przyczyną są także przemiany demograficzne, tzn. starzenie się ludności w krajach europejskich, która preferuje pasywne formy turystyki i stanowi obecnie, a także będzie stanowić w przyszłości, znaczący udział wśród turystów odwiedzających te tereny.

\section{UZDROWISKA}

$\mathrm{Na}$ obszarach górskich, ze względu na specyficzne środowisko przyrodnicze, zwłaszcza budowę geologiczną i warunki klimatyczne, skupia się najwięcej uzdrowisk. Funkcja lecznicza uzdrowisk traci jednak na znaczeniu. Kryzys leczenia uzdrowiskowego spowodowany jest postępem w medycynie, np. w zakresie laryngologii, reumatyzmu oraz ograniczeniem wsparcia finansowego ze środków państwowych. Obecne uzdrowiska to $\mathrm{w}$ większości ośrodki wypoczynku, wzmacniania zdrowia, uprawiania sportów, np. narciarstwa, a ostatnio także centra kongresowe, miejsca organizacji festiwali filmowych i różnych imprez kulturalnych. Silnie for instance in 2001 the cost of a onenight stay was 26 euros, at the seaside 34 , and in the city -45 , as a result of the smaller tourism and entertainment offer. Also in France, tourists staying at agrotourism farms come from the less welloff, mainly families with children (60\%) http://www.ifen.fr/presse/dostour.htm

\section{TOURISM IN PROTECTED AREAS}

Protected areas are established in order to preserve valuable natural and cultural heritage, as well as for recreational and educational purposes. Tourism and conservation are closely related, the former often stimulating the latter, but on the other hand it can also be a threat. The larger the demand for recreation in areas of high natural value, the larger the threat (JAFARI 2000).

The popularity of protected areas used for tourism and recreational purposes is bound to grow rapidly due to several factors. One of them is the growing interest in the educational, natural and eco-tourism which flourish in mountain areas. Another significant cause is the ageing of the population in European countries preferring passive forms of tourism and these will certainly make up a considerable proportion of tourists visiting these areas.

\section{SPAS}

Due to the particular nature of the mountain environment, especially geology and climate, there are plenty of spas to be found. The medical function of spas, however, is losing its significance as a result of progress in medicine, for instance in laryngology or rheumatism treatment, and from limited state subsidies. Today's spas are mostly holiday centres where health can be improved and with sports such as skiing while recently they have also become centres where congresses, film festivals and other 
rozwiniętą funkcją turystyczno-wypoczynkową wyróżniają się zwłaszcza uzdrowiska górskie, co związane jest $\mathrm{z}$ ich atrakcyjnością dla wielu form turystyki, zarówno w sezonie zimowym, jak i w letnim (np. dla uprawiania turystyki pieszej, narciarstwa).

\section{KONCEPCJE HARMONIJNEGO ROZWOJU TURYSTYKI}

Najbardziej popularnymi koncepcjami harmonijnego rozwoju turystyki są ekoturystyka i turystyka zrównoważona.

Ekoturystyka to formy turystyki bazujące na zasobach przyrodniczych, przy założeniu, że głównym motywem turystów jest obserwacja i podziwianie przyrody oraz poznawanie tradycyjnej kultury. Zasady ekoturystki (np. minimalny wpływ na środowisko, partycypowanie w kosztach ochrony środowiska, dostosowana frekwencja turystów do chłonności obszaru) nie są spełniane przez większość obecnych form turystyki spotykanych na obszarach górskich.

Bardziej kompleksowy chaakter ma koncepcja zrównoważonej turystyki. Jej główne zasady to:

- racjonalne wykorzystywanie przez turystykę zasobów naturalnych i kulturowych,

- udział turystyki w ochronie zasobów naturalnych i dziedzictwa kulturowego,

- włązzenie turystyki w system planowania,

- rozwój właściwych form turystyki,

- zasilanie lokalnej gospodarki przez turystykę,

- udział lokalnej społeczności w istotnych decyzjach dotyczących turystyki,

- kształcenie i przygotowanie zawodowe lokalnej społeczności do pracy w turystyce,

- rozwój nowych dziedzin zatrudnienia,

- właściwe zarządzanie ograniczające negatywne skutki rozwoju turystyki (WWF 1992).

Cechami sprzyjającymi rozwojowi turystyki zrównoważonej na obszarach górskich są m.in.: dobrze zachowany i pielęgnowany krajobraz, rolnictwo ekologiczne, sztuka regionalna oraz tradycyjny styl budownictwa.

Najlepszymi formami turystyki powinny być: turystyka przyrodnicza, kulturowa i edukacyjna. Aktywne formy turystyki i rekreacji, a zwłaszcza narciarstwo, które są szkodliwe dla środowiska, nie powinny być natomiast dozwolone na obszarach o cennych walorach przyrodniczo-krajobrazowych. cultural events are held. A strong tourism and recreational function can be seen in mountain spas due to their attractive conditions for many forms of tourism. both in winter and summer (walking and skiing).

\section{CONCEPTS OF HARMONIOUS TOURISM DEVELOPMENT}

The most popular concepts of a harmonious tourism development are eco-tourism and sustainable tourism. Eco-tourism includes those forms based on natural resources, assuming that the tourists' main motives are the observation and admiration of nature, as well as learning about traditional culture. The principles of eco-tourism (e.g. minimum effect on the environment, participating in the costs of nature protection and adjusting the number of tourists to the area's carrying capacity) are not followed in most kinds of tourism in mountain areas.

The concept of sustainable tourism is more comprehensive and its main assumptions are (WWF 1992):

- rational exploitation of natural and cultural resources by tourism;

- participation of tourists in natural and cultural resource preservation;

- including tourism in the planning system;

- developing appropriate forms of tourism;

- reinforcing the local economy by tourism;

- participation of local communities in decisions regarding tourism;

- educating and training the local community for work in tourism;

- developing new areas of employment;

- eco-management limiting the negative effects of tourism development.

The development of balanced tourism in mountain areas is enhanced by a wellpreserved landscape, ecological agriculture, regional art, traditional architectural styles etc. The best forms of tourism should be nature-oriented, cultural and educational. Active forms of tourism and recreation, especially skiing, which are harmful for the 
Istotna jest zasada, aby natężenie ruchu turystycznego na terenach wykorzystywanych dla turystyki i rekreacji nie przekraczało granic chłonności turystycznej, zaś obiekty i urządzenia turystyczne (noclegowe, sportowo-rekreacyjne itd.) powinny być właściwie zlokalizowane i dostosowane pod względem architektonicznym do krajobrazu przyrodniczego i kulturowego.

$\mathrm{Na}$ obszarach recepcji turystycznej jednym $\mathrm{z}$ priorytetów strategii rozwoju turystyki powinno być ograniczenie indywidualnego ruchu samochodowego. Promowane powinny być publiczne środki transportu, rowery i ruch pieszy.

Do najważniejszych zasad zrównoważonego rozwoju turystyki należy też poprawa poziomu życia lokalnej społeczności.

W celu realizacji strategii rozwoju turystyki zrównoważonej konieczne jest stosowanie odpowiedniej polityki regionalnej oraz zapewnienie prawnych warunków jej rozwoju. Są to na przykład:

- kontrola użytkowania ziemi,

- kontrola planowania nowych inwestycji,

- kontrola nielegalnego budownictwa drugich domów,

- określenie standardów i norm dotyczących środowiska (wody pitnej, wody użytkowanej do celów rekreacyjnych, emisji gazów i pyłów itp.),

- tworzenie obszarów prawnie chronionych,

- zarządzanie ruchem drogowym i ograniczanie ruchu samochodowego,

- ograniczanie liczby turystów (Tourism and Recreation 2001).

Działania uwzględniające idee zrównoważonego rozwoju obszarów górskich prowadzi się już od wielu lat. Ogranicza się negatywne dla środowiska przyrodniczego skutki masowej turystyki, stosując między innymi optymalne rozwiązania techniczne oraz rygorystyczną i konsekwentną politykę ochrony środowiska. Innym rozwiązaniem jest propagowanie różnych form turystyki alternatywnej, w tym turystyki ekologicznej.

Jednym z elementów strategii zrównoważonego rozwoju gór może być koegzystencja rolnictwa i turystyki. Od rolnictwa bowiem zależeć może w dużym stopniu przyszłość obszarów górskich. Zamieszkałe od wieków tereny górskie są przykładem harmonii pomiędzy przyrodą a gospodarką człowieka. Rolnicy odgrywają tu rolę strażników kulturowego krajobrazu, co jest niezwykle istotne $\mathrm{z}$ punktu widzenia turystyki.

Za najważniejsze zadania mające na celu realizację idei zrównoważonego rozwoju należałoby uznać: environment should not be allowed in areas of high natural and landscape value.

It is important that activities in areas used for tourism and recreation purposes does not exceed the carrying capacity limits, that infrastructure (accommodation, sport and recreation facilities, etc.) is suitably distributed, and the architecture matches the natural and cultural landscape. In tourism reception areas, one of the development priorities should be the limiting of vehicular traffic with public transport, bicycles and walking being promoted instead. One of the most important assumptions of sustainable tourism development is an improvement in the standard of living among the local community.

In order to put this strategy into practice it is necessary to introduce a suitable regional policy as well as guarantee legal conditions such as (Tourism and Recreation 2001):

- control over land exploitation;

- control over planning new investments;

- control over the illegal building of second homes;

- setting standards and norms regarding the environment (drinking water, water used for recreational purposes, gas and dust emission, etc.);

- establishing legally protected areas;

- organising and limiting vehicular traffic;

- limiting the number of tourists.

Activities respecting the ideas of sustainable tourism development in mountain areas have been present for many years. The negative effects of mass tourism are being reduced by applying optimum technological solutions and a rigorous and consistent policy of environmental protection. Another solution is the promotion of various forms of alternative tourism, including eco-tourism.

One element of the strategy could be the co-existence of agriculture and tourism as it is in agriculture that the future of mountain areas may largely depend. Mountains, inhabited for centuries, are an example of harmony between nature and the human economy. Farmers play a role in the cultural landscape guardians which is extremely important from the point of view of tourism. 
- ochronę środowiska, ponieważ jest ono najważniejszym elementem zasobów turystycznych,

- doprowadzenie do ścisłego powiązania turystyki z lokalną gospodarką i ograniczenie odpływu dochodów z turystyki,

- stosowanie strategii zapewniającej odpowiednie warunki życia ludności miejscowej poprzez jej zatrudnienie w sektorze turystycznym oraz pomoc $w$ rozwijaniu małych przedsiębiorstw,

- opracowanie projektów rozwoju turystyki nie tylko z punktu widzenia krajowego i zagranicznego turysty, ale także lokalnej społeczności,

- ograniczenie negatywnych skutków społecznych rozwoju turystyki,

- kształcenie lokalnej ludności w zawodach związanych $\mathrm{z}$ produkcją na potrzeby turystyki i w usługach turystycznych.
A policy leading to sustainable development includes:

- protecting the environment, as it is the most important tourism resource;

- aiming at a close relation between tourism and the local economy, limiting the outflow of tourism-generated income;

- using a strategy which secures adequate living conditions for local residents by employing them in the tourism sector; helping the development of small businesses;

- planning tourism development not only from the point of view of local and foreign tourism, but also the local community;

- reducing the negative social effects of tourism development;

- educating local inhabitants in professions related to tourism production and services.

\section{BIBLIOGRAFIA - BIBLIOGRAPHY}

An Appeal for the Mountains, 1992, UNCED, Rio de Janeiro.

BACHLEITNER R., (Hrsg.), 1998. Alpiner Wintersport. Eine sozial-, wirschafts-, tourismus- und ökowissenschaftliche Studie zum Alpinen Skilauf. Snowboarden und anderen alpinen Trendsportarten, Studien Verl., Innsbruck, Wien.

Barbier B., herbin J., Billet J., Bevilacgua e., Jülg F. GRÄF P., GOSAR A., 1984, Le tourisme alpin. 25e Congres International de Géographie. Paris-Alpes.

BÄTZING W., 1991, Die Alpen. Entstehung und Gefährdung einer europäischen Kulturlandschaft. München.

BÄtzing W., Messerli P.. 1991. Die Alpen im Europa der neunziger Jahre - ein ökologisch gefährdeter Raum im Zentrum Europas zwischen Eigenstïndigkeit und Abhängigkeit, Geographisches Institut der Universität Bern. Bern.

Breiling M., Charamza P., 1999. The impact of global warming on winter tourism and skiung: a regionalised model for Austrian snow conditions, [w:] Regional Environmental Change, Journal Springer Verlag, Berlin.

Brugger E., A., Furrer G., Messerla B., Messerli P. (eds.), 1984, The Transformation of Swiss Mountain Regions. Problems of development between selfreliance and dependency in an economic and ecological perspective, Bern-Stuttgart.

Cater E., Lowman, G. (eds.) 1994, Ecotourism: A Sustainable Option? Wiley, Chichester.

EMBACHER H., 2001, Struktury organizacyjne $w$ agroturystyce. Przykład Austrii. [w:] J. Majewski, B. Lane (red.). Turystyka wiejska i rozwój lokalny. Fundacja Fundusz Współpracy, Poznań.

HuNTER C., GREEN M., 1995. Tourism and the environment. A sustainable relationship?, London.

JAFARI J., 2000, Encyclopedia of Tourism, Routledge, London. New York.
JAGuSiEwicz A., 1999, Problemy funkcjonowania lecznictwa $i$ turystyki $w$ uzdrowiskach, . Rynek Turystyczny”. nr $13 / 14$

JАMOT C., 2003., Les stations thermales du Massif Central en quete d'avenir, [w:] W. Kurek (red.). Issues of tourism and health resort management. Inst. Geografii i Gospodarki Przestrzenncj UJ, Prace Geograficzne, z. 111.

KUREK W.,1996, Agriculture Versus Tourism in Rural Areas of the Polish Carpathians, GeoJournal, vol. 38 no. 2.

Les chiffres clés du tourisme de montagne en France 2001. Direction du Tourisme, service d'Etudes et d'Aménagement touristique de la montagne.

LiCHTENBERGER E., 1975, The Eastern Alps, Oxford University Press.

PILS M., Glauser P., Siegrist D. (eds), 1996. Green Paper on the Alps.The Alps Touchstone for Europe, Nature Friends International, Wien.

SMith C., JenNer P., 2000, Health Tourism in Europe. „Travel and Tourism Analyst”, nr 1.

Tourism and Recreation - Europe's Environment: The Dobris Assessment (Chapter 25), 2001, European Environment Agency, Copenhagen.

Tirol. Zahlen \& Fakten. 2004, Innsbruck.

WARSZYNSKA J. (red.), 1995, Karpaty Polskie. Przyroda. człowiek i jego działalność. Kraków.

WEATHERley R., D., NAYlon J., 1984, Domestic tourism and second homes as motors of rural evelopment in the Sierra Morena, Spain, [in:] R. Majoral, F. Lopez (eds), Rural life and the explotation of natural resources in highlands and high-latitude zones, Barcelona.

ZimMERMANN F. M., 1995. The Alpine Region: Regional Re structuring Opportunities and Constraints in a Fragile Environment, [in:] A. Montanari and A. M. Williams (eds), European Tourism: Regions, Spaces and Restructuring. Wiley, Chichester-New York. 